\title{
PRODUCTIVE RESPONSES FROM BROILER CHICKENS RAISED IN DIFFERENT COMMERCIAL PRODUCTION SYSTEMS - PART I: FUZZY MODELING
}

\author{
Dian Lourençoni ${ }^{1 *}$, Tadayuki Yanagi Junior ${ }^{2}$, Paulo G. de Abreu ${ }^{3}$, Alessandro T. Campos ${ }^{2}$, \\ Silvia de N. M. Yanagi
}

${ }^{1 *}$ Corresponding author. Universidade Federal do Vale do São Francisco/ Juazeiro - BA, Brasil.

E-mail: dian.lourenconi@univasf.edu.br ORCID ID: https://orcid.org/0000-0003-1173-2381

\section{KEYWORDS}

poultry farming, productive performance, artificial intelligence, fuzzy logic.

\begin{abstract}
Broiler chickens are classified as homoeothermic animals and require a production environment within well-defined thermal comfort intervals. Therefore, the development of algorithms (mathematical models) to control the environment that can be embedded in microcontrollers becomes necessary. Hence, this work aimed to develop a fuzzy model for predicting the productive performance of broiler chickens as a function of the thermal environment during the various breeding phases. The Mamdani inference and defuzzification methods were used, by means of the gravity center, to develop the fuzzy model. Two hundred and forty-three rules with weighting factors of 1.0 each were elaborated. Three commercial warehouses (conventional system, wind tunnel with negative pressure and dark house) were evaluated for testing of the model. We recorded the thermal environment (dry bulb temperature - $t_{d b}$ and relative humidity - RH) and productivity data (feed intake - FI, weight gain - WG, feed conversion - FC and productive efficiency index - PEI) over six lots in each aviary. The resulting fuzzy model was capable of forecasting FI, WG, FC, and PEI, with standard deviations and mean percentage errors of $4.16 \mathrm{~g}$ and $5.05 \%, 146.53 \mathrm{~g}$ and $8.04 \%, 0.06 \mathrm{~g} \mathrm{~g}^{-1}$ and $4.96 \%$, and $24.51 \mathrm{~g}$ and $12.29 \%$, respectively.
\end{abstract}

\section{INTRODUCTION}

The development of the Brazilian poultry industry has been supported by the adoption of new methodologies and technologies that seek the optimization of animal production, allowing the improvement of sector competitiveness, faced with the new demands of the consumer market.

The production environment is one of the major causes of losses in animal production on a commercial scale. For animals to express their genetic potential, among other requirements, it is necessary to provide adequate food and an aseptic and thermally adjusted environment that meets the needs of the chicken (Yanagi Junior et al., 2011; Abreu et al., 2012; Almeida \& Passini, 2013; Campos et al., 2013b; Nascimento et al., 2014; Tinôco et al., 2014).

Broiler chickens are classified as homoeothermic animals, i.e., they are capable of maintaining their body temperature within relatively narrow limits by means of physiological and behavioral mechanisms. However, when the thermal environment exceeds the limits of comfort, the energy used for meat production is spent in thermoregulatory processes, leading to production losses (Baracho et al., 2013; Boiago et al., 2013; Lara \& Rostagno, 2013; Castro, 2014; Santos et al., 2014).

Therefore, maintaining the thermal environment within ranges of comfort is paramount for the genetic potential of the lineage to be achieved. This demands the development of algorithms (mathematical models) of environment control that can be embedded in microcontrollers. Among the possible models to be developed, those based on artificial intelligence, specifically the fuzzy set theory, seem to be quite adequate according to animal comfort studies (Gates et al., 2001; Castro et al., 2012; Ponciano et al., 2012; Campos et al., 2013a; Aborisade \& Stephen, 2014; Ferraz et al., 2014; Xiang-Jie, 2014; Julio et al., 2015; Mirzaee-Ghalehv et al., 2015; Schiassi et al., 2015; Zare Mehrjerdi et al., 2015).

However, few fuzzy models have been developed or validated based on data obtained under commercial production conditions, and when this is the case, data often

\footnotetext{
${ }^{2}$ Universidade Federal de Lavras/ Lavras - MG, Brasil.

${ }^{3}$ Embrapa Suínos e Aves/ Concordia - SC, Brasil.

Received in: 7-11-2018

Accepted in: 10-29-2018
} 
come from one single lot and breeding system. A fuzzy mathematical model based on different commercial production systems and on a significant number of broiler lots raised in these systems can predict the performance of the broiler chickens independently of the system being used.

With this in mind, this study aimed to develop a fuzzy model to forecast the productive performance of broiler chickens raised in different commercial production systems.

\section{MATERIAL AND METHODS}

\section{Breakdown of productive systems}

Three commercial aviaries (conventional, tunnel with negative pressure and dark house) raising broilers were evaluated for 12 months to develop and test the fuzzy model. The aviaries are located in the municipality of Concórdia, Santa Catarina (SC), Brazil, whose regional climate is classified as $\mathrm{Cfa}$, i.e., a warm temperate climate with hot summers, according to the Köppen classification (Peel et al., 2007).

The conventional system (Figure 1 ) had $12 \times 100 \times$ $2.4 \mathrm{~m}$ dimensions (width, length, and ceiling), a two-piece roof with $6 \mathrm{~mm}$ thick asbestos cement tiles, an East-West orientation, $0.45 \mathrm{~m}$ high side walls, yellow lining, and side curtains. The aviary had two lighting lines with sixteen 40 W tubular fluorescent lamps each for a total of 32 lamps. Chick warming during the initial phases was made by a drum with wood and gas lamp heaters. The aviary had cross ventilation (positive pressure), with 10 fans and four lines with 10 nebulizers each, longitudinally distributed, totaling 40 water emitters. The bed was made up of new shavings at the beginning of the first batch.

The fans had a $0.5 \mathrm{HP}$ power single-phase induction engine and 240 to $280 \mathrm{~m}^{3} \mathrm{~min}^{-1}$ flow (3-blade fan). The drive occurred in three stages: stage 1 (four fans); stage 2 (eight fans), and stage 3 (10 fans). Stage 1 was turned on at $27.0^{\circ} \mathrm{C}$ air dry bulb temperature $\left(\mathrm{t}_{\mathrm{db}}\right)$, stage 2 was turned on at $27.2^{\circ} \mathrm{C}$, and stage 3 was turned on at $27.5^{\circ} \mathrm{C}$. The highpressure nebulizers $\left(180 \mathrm{kgf} \mathrm{cm}^{-2}\right)$ had a $6.5 \mathrm{~L} \mathrm{~h}^{-1}$ flow rate, and the three-phase pump engine system had a 7 HP power output. The nebulizers were activated when the relative air humidity (RH) was below $70 \%$.

The adopted light program was as follows: from the $1^{\text {st }}$ to the $3^{\text {rd }}$ day ( 24 hours of light), from the $4^{\text {th }}$ to the $7^{\text {th }}$ day ( $22 \mathrm{~h}$ of light), from the $8^{\text {th }}$ to the $21^{\text {st }}$ day ( $20 \mathrm{~h}$ of light), and from the $22^{\text {nd }}$ day until slaughter (16 h of light). Water and food were supplied ad libitum, and the curtains were handled in accordance with the climate conditions.
A

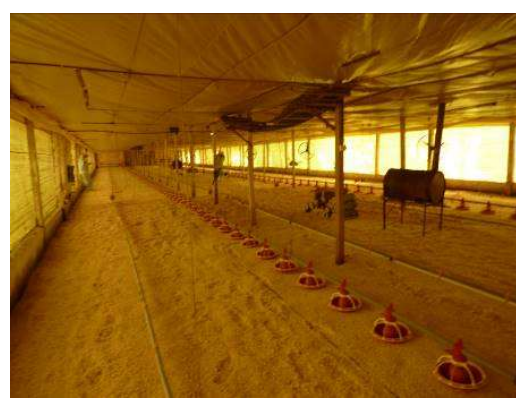

B

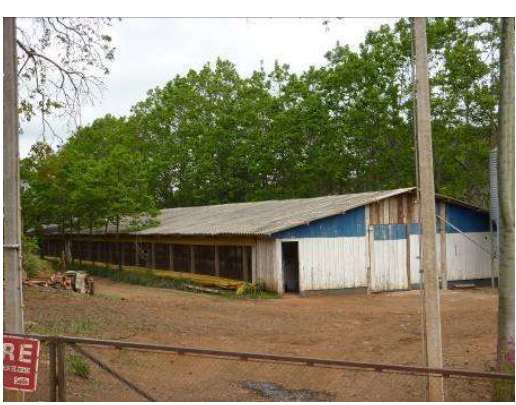

$\mathrm{C}$

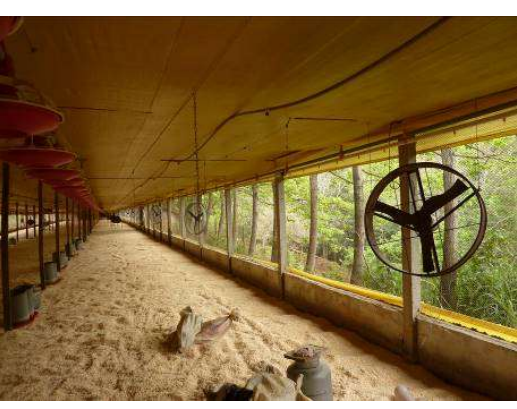

FIGURE 1. (A) Internal view, (B) external view, and (C) detail of fan in the conventional system aviary.

The negative pressure system aviary (Figure 2) had $12 \times 100 \times 2.4 \mathrm{~m}$ (width, length, and ceiling) dimensions, a two-piece roof with French ceramic tiles, an East-West orientation, $0.43 \mathrm{~m}$ high side walls, a yellow lining, and side curtains. The aviary had two lighting lines with sixteen 25 W compact tubular fluorescent lamps each, giving a total of 32 lamps Chicken warming during the initial phases was made by gas lamp heaters. The aviary had tunnel ventilation (negative pressure) with eight exhaust fans and eight lines with eight nebulizers distributed parallel to the width of the aviary, totaling 64 water emitters. The bed was made up of new shavings at the beginning of the first batch.

The exhaust fans had three blades with a diameter of $1.80 \mathrm{~m}$, a single-phase induction engine with a power of 1
$\mathrm{HP}$, and a flow between 441 and $564 \mathrm{~m}^{3} \mathrm{~min}^{-1}$. The drive occurred in four stages: stage 1 (two exhaust fans); stage 2 (four exhaust fans); stage 3 (six exhaust fans); and stage 4 (eight exhaust fans). Stage 1 corresponded to the minimum ventilation condition, and was always on, stage 2 was turned on at $\mathrm{t}_{\mathrm{db}} \geq 28{ }^{\circ} \mathrm{C}$, stage 3 at $\mathrm{t}_{\mathrm{db}} \geq 29^{\circ} \mathrm{C}$, and stage 4 at $\mathrm{t}_{\mathrm{db}} \geq$ $30^{\circ} \mathrm{C}$. High pressure nebulizers $\left(180 \mathrm{kgf} \mathrm{cm}^{-2}\right)$ with a $6.5 \mathrm{~L}$ $\mathrm{h}^{-1}$ flow rate and two HP two-phase pump engine system were used. The nebulizers were turned on at $t_{\mathrm{db}} \geq 31{ }^{\circ} \mathrm{C}$.

The adopted light program was as follows: from the $1^{\text {st }}$ to the $2^{\text {nd }}$ day ( $24 \mathrm{~h}$ of light), from the $3^{\text {rd }}$ to the $7^{\text {th }}$ day ( $23 \mathrm{~h}$ of light), from the $8^{\text {th }}$ to the $35^{\text {th }}$ day ( $14 \mathrm{~h}$ of light), and from the $36^{\text {th }}$ day until slaughter ( $22 \mathrm{~h}$ of light). Water and food were supplied ad libitum, and the curtains remained closed. 
A

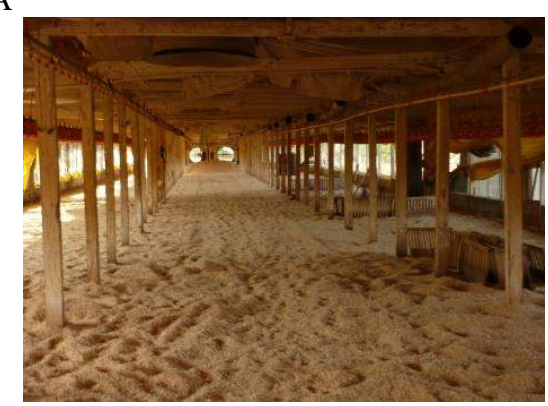

B

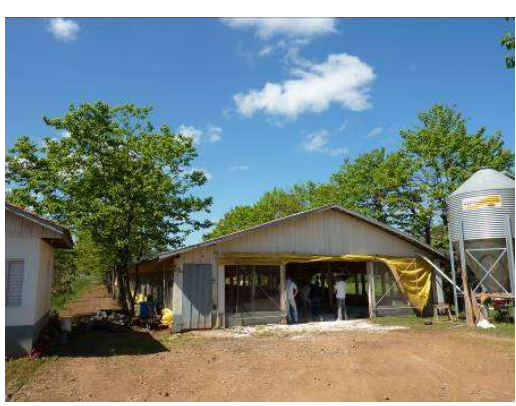

$\mathrm{C}$

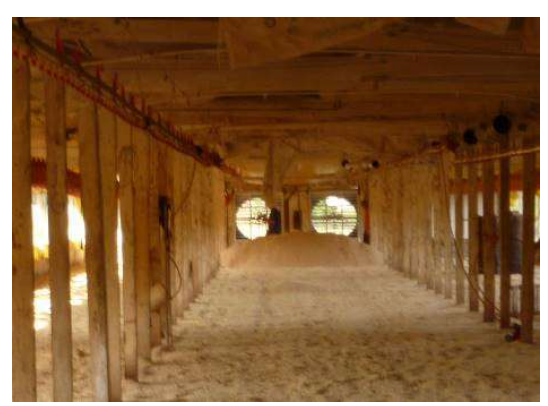

FIGURE 2. (A) Internal view, (B) external view, and (C) detail of exhaust fans in the negative Pressure system aviary.

The dark house system aviary (Figure 3) had dimensions of $2 \times 100 \times 2.2 \mathrm{~m}$ (width, length, and ceiling), a two-piece French ceramic tiles roof, an East-West orientation, $0.45 \mathrm{~m}$ high side walls, and side curtains, black on the inner face and silver on the outer face. The aviary had two lighting lines with twenty $100 \mathrm{~W}$ compact tubular fluorescent lamps each for a total of 40 lamps. Chicken warming during the initial phases was achieved with a wood furnace. The aviary had tunnel ventilation (negative pressure) with eight exhaust fans and eight lines with eight nebulizers distributed parallel to the width of the aviary for a total of 64 water emitters, and a wet-brick evaporative cooling system, with two boards with a length of $15 \mathrm{~m}$, and three lines with 18 nebulizers externally distributed on the brick plate (totaling 54 water emitters). The bed was made up of new shavings at the beginning of the first batch.
Three blade exhaust fans with a diameter of $1.80 \mathrm{~m}$, a three-phase induction engine with a power of $1 \mathrm{HP}$, and a flow rate between 441 and $564 \mathrm{~m}^{3} \mathrm{~min}^{-1}$ were used. The drive occurred in four stages: stage 1 (two exhaust fans); stage 2 (four exhaust fans); stage 3 (six exhaust fans), and stage 4 (eight exhaust fans). Stage 1 corresponded to minimum ventilation $\left(\mathrm{t}_{\mathrm{db}} \leq 22{ }^{\circ} \mathrm{C}\right)$, stages 2,3 , and 4 were turned on at $\mathrm{t}_{\mathrm{db}} 23^{\circ} \mathrm{C}, 24^{\circ} \mathrm{C}$, and $25^{\circ} \mathrm{C}$, respectively. High pressure nebulizers $\left(180 \mathrm{kgf} \mathrm{cm}^{-2}\right)$ with $6.5 \mathrm{~L} \mathrm{~h}^{-1}$ flow rate and $7 \mathrm{HP}$ three-phase pump engine system were used. Evaporation plates and nebulizers were turned on at $\mathrm{RH}$ below $70 \%$ and $65 \%$, respectively.

The adopted light program was as follows: from the $1^{\text {st }}$ to the $3^{\text {rd }}$ day ( $24 \mathrm{~h}$ of light), from the $4^{\text {th }}$ to the $21^{\text {st }}$ day ( $10 \mathrm{~h}$ of light), from the $22^{\text {nd }}$ to the $35^{\text {th }}$ day ( $8 \mathrm{~h}$ of light), and from the $36^{\text {th }}$ day until slaughter ( $22 \mathrm{~h}$ of light). Water and food were provided at will (ad libitum), and the curtains were always closed.
A

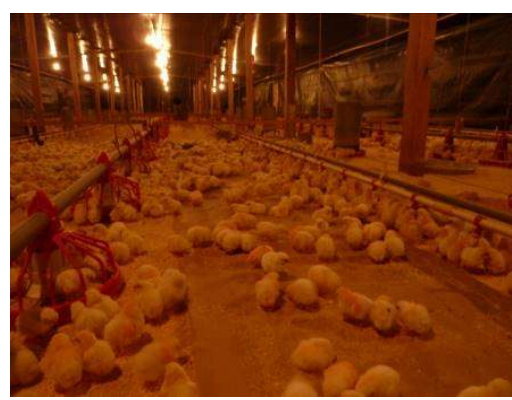

B

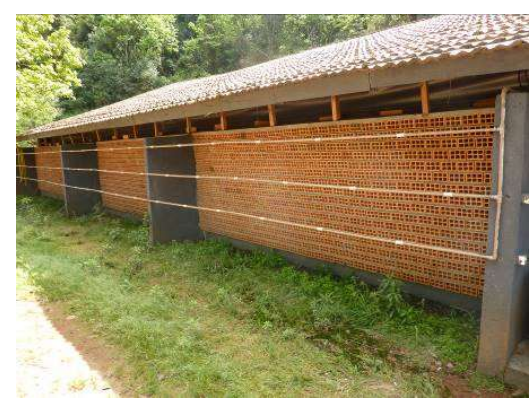

C

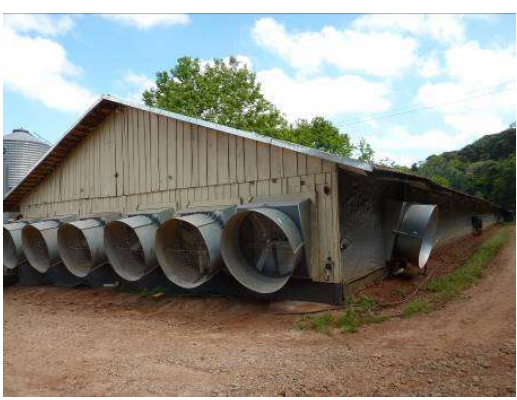

FIGURE 3. (A) Internal view, (B) external view, and (C) detail of exhaust fans in the dark house system aviary.

\section{Animals and measurements}

Six lots of Cobb lineage broilers were created in each poultry. The stocking densities of the birds in conventional, negative pressure, and dark house aviaries were 12.00 to 12.92 birds $\mathrm{m}^{-2}, 12.83$ to 14.00 birds $\mathrm{m}^{-2}$, and 14.50 to 15.58 birds $\mathrm{m}^{-2}$, respectively. The thermal and the productive responses of the chickens were the studied variables.

The thermal environment was studied through the averages of variables, such as $\mathrm{t}_{\mathrm{db}}$ (HOMIS 404A, $\pm 0.5{ }^{\circ} \mathrm{C}$ accuracy, and $0.1{ }^{\circ} \mathrm{C}$ resolution) and RH (HOMIS 404A, \pm $2.5 \%$ accuracy, and $0.1 \%$ resolution) collected every $6 \mathrm{~h}$ for six consecutive batches at 12 uniformly distributed points inside the structure and one external point at the birds' heights ( $30 \mathrm{~cm}$ from the bed) (Figure 4). Besides $t_{d b}$ and $\mathrm{RH}$, the internal environment was also characterized by enthalpy (H), which was calculated using [eq. (1)] (Albright, 1990) and the average data collected at the 12 points.

$$
H=1,006 \times t_{d b}+W \times\left(2501+1,805 \times t_{d b}\right)
$$

Where,

$\mathrm{H}$ is the enthalpy $\left(\mathrm{kJ} \mathrm{kg}_{\mathrm{dry}}{ }^{-1}{ }^{-1}\right)$;

$\mathrm{t}_{\mathrm{db}}$ is the air dry bulb temperature $\left({ }^{\circ} \mathrm{C}\right)$, and

$\mathrm{W}$ is the mixing ratio $\left(\mathrm{kg}_{\mathrm{water} \text { vapor }} \mathrm{kg}_{\text {dry air }}{ }^{-1}\right)$.

The mixing ratio was calculated by [eq. (2)] as a function of current water vapor pressure (ea, $\mathrm{kPa})$ and the local atmospheric pressure $\left(\mathrm{P}_{\mathrm{atm}}, \mathrm{kPa}\right)$.

$$
\mathrm{W}=0,622 \times\left(\frac{e a}{\mathrm{P}_{\mathrm{atm}}}\right)
$$




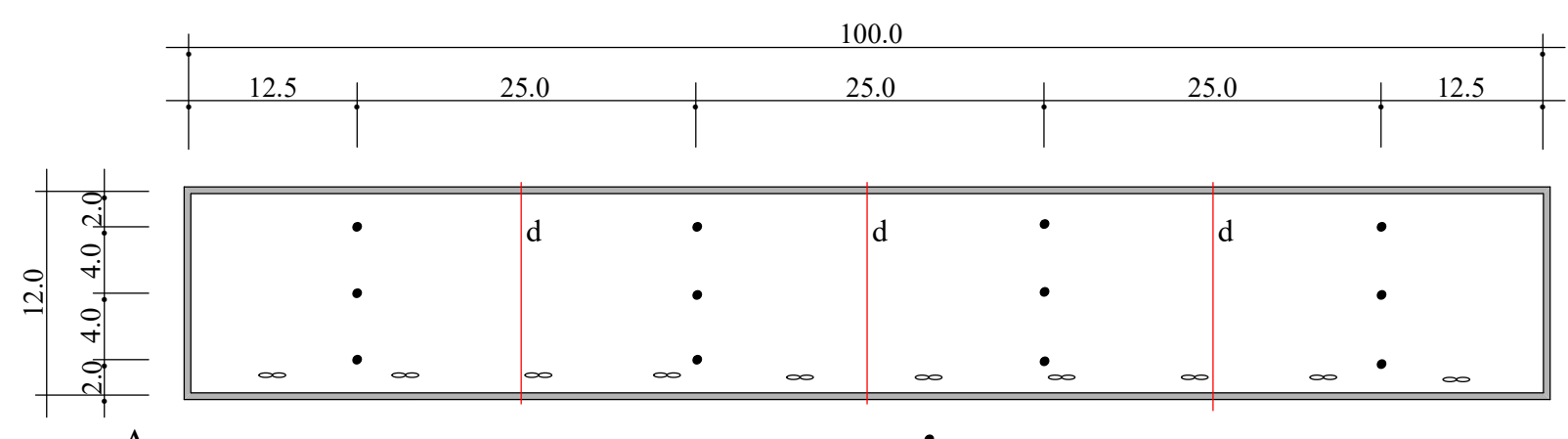

A

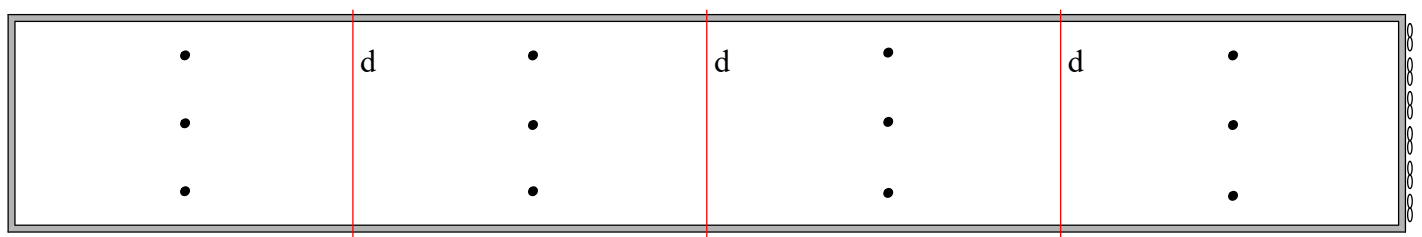

$\mathrm{B}$

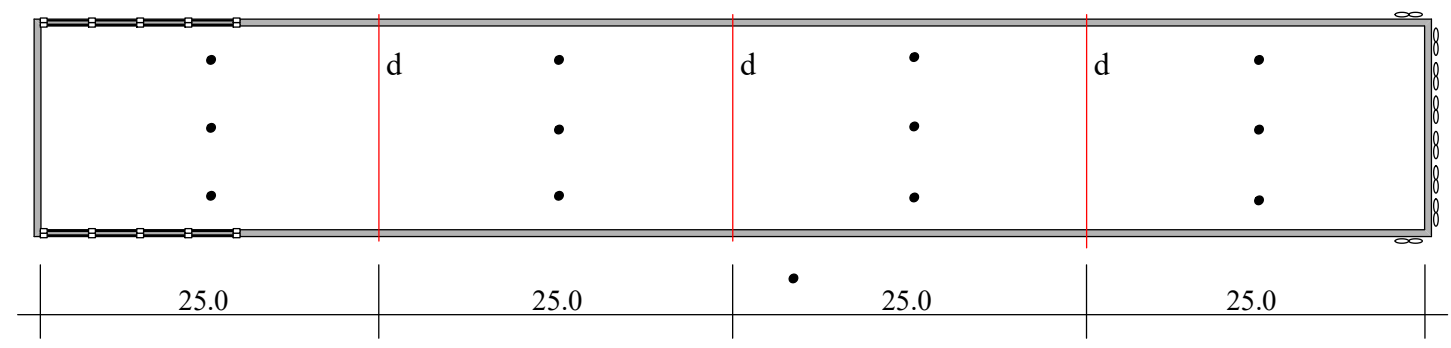

$\overbrace{}^{N}$

\begin{tabular}{|cl|cl|}
\hline$\bullet$ & Collection points & $=$ & Evaporation plates \\
\hline$\infty$ & Fans/Exhaust fans & $\mathrm{d}$ & Internal divisions \\
\hline
\end{tabular}

FIGURE 4. Sketch of aviaries. A - conventional system, B - negative pressure system, and C - conventional system with a sensor distribution scheme. (Unit: $\mathrm{m}$ ).

We evaluated the following productive responses: food intake (FI), mean weight gain (WG), mean feed conversion (FC), and productive efficiency index (PEI). The FI was calculated as a function of the amount of food consumed during the considered period divided by the period in days. WG was obtained by the difference between chickens' live weights at the end and at the beginning of the life phase of each batch. Feed conversion (FC) is the ratio between the amount of consumed food and the weight gain corresponding to the considered period of time, and the inverse ratio is called feed efficiency. The productive efficiency index (PEI) is calculated as a function of live weight, viability, age, and feed conversion (FC) by [eq. (3)].

$$
\mathrm{PEI}=\left(\frac{\mathrm{W} \times \mathrm{V}}{\mathrm{A} \times \mathrm{FC}}\right) \times 100
$$

Where,
W represents the birds' live weights $(\mathrm{kg})$;

$\mathrm{V}$ is viability (\%);

A represents the birds' ages in days, and

$\mathrm{FC}$ is the feed conversion $\left(\mathrm{g} \mathrm{g}^{-1}\right)$.

The viability (recorded as a percentage) is the difference between the housed birds and those removed for slaughter.

\section{Development and validation of the fuzzy model}

The Mamdani inference method (Mandani, 1976), adopted by several authors (Ponciano et al., 2012; Lin et al., 2013; Múnera Bedoya et al., 2015; Schiassi et al., 2015), was used for the development of the fuzzy model, and offers as a response, a fuzzy set arising from the combination of input values with their respective pertinence degrees through a minimum operator followed by rules overlapping through a maximum operator (Leite et al., 2010). The defined input variables were the enthalpies $(\mathrm{H})$ in the birds' life phases defined in Table 1 and represented by trapezoidal pertinence curves (Figure 5), which were chosen to better reproduce the data set (Schiassi et al., 2015). 
TABLE 1. Divisions of the birds' life stages and their respective descriptions.

\begin{tabular}{cc}
\hline Stages & Description \\
\hline 1 & $1^{\text {st }}$ week of life (initial stage) \\
2 & $2^{\text {nd }}$ week of life (initial stage) \\
3 & $3^{\text {rd }}$ week of life (initial stage) \\
4 & $4^{\text {th }}$ and $5^{\text {th }}$ weeks of life (growing stage) \\
5 & $6^{\text {th }}$ week of life on (final stage) \\
\hline
\end{tabular}

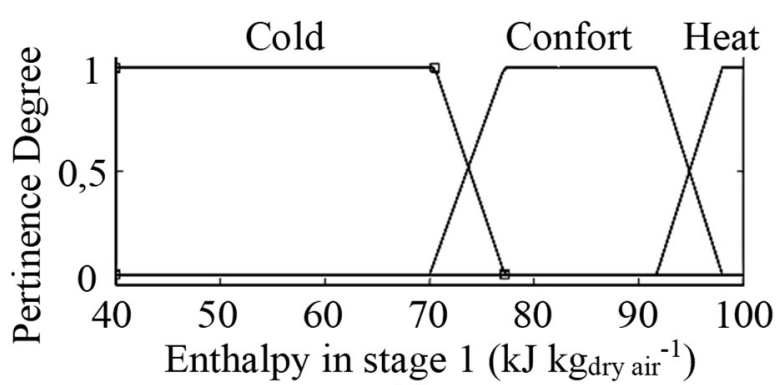

(a)

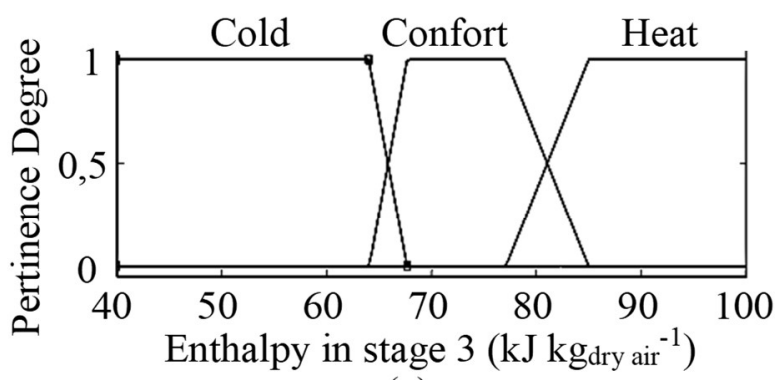

(c)

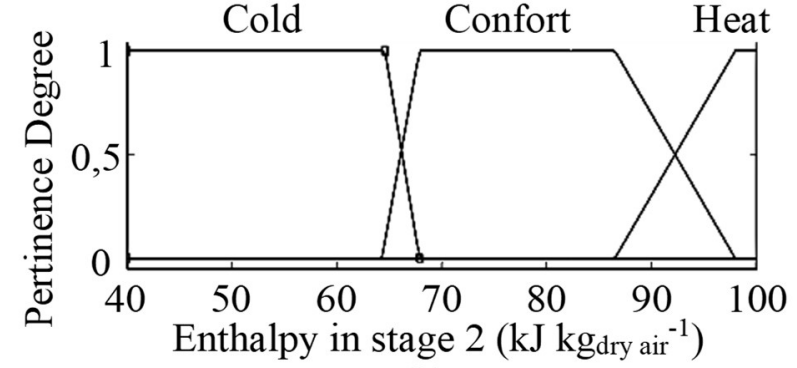

(b)

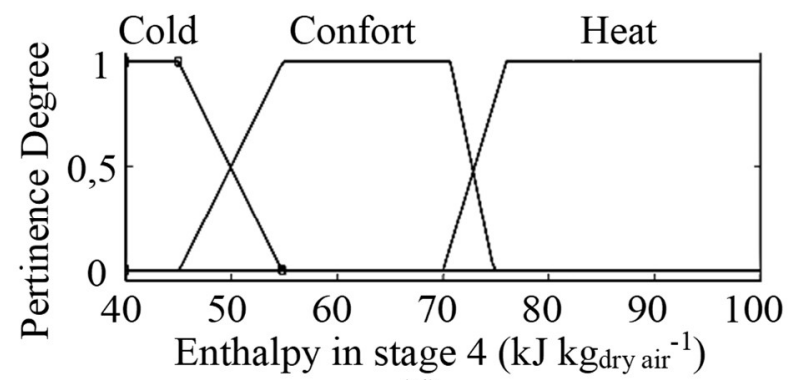

(d)

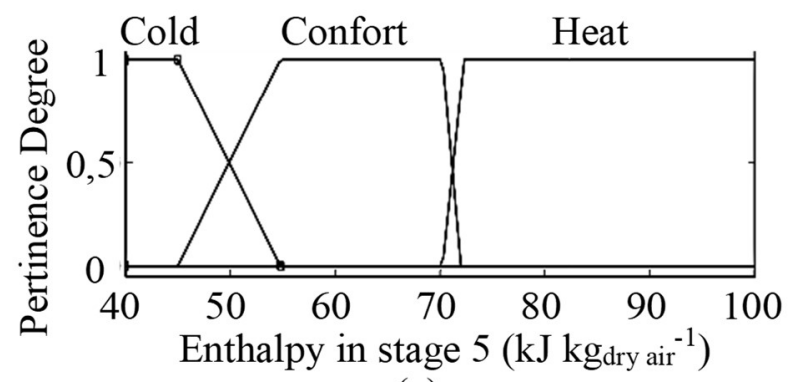

(e)

FIGURE 5. Pertinence functions for the input variables: (a) Enthalpy in phase 1, (b) Enthalpy in phase 2, (c) Enthalpy in phase 3, (d) Enthalpy in phase 4, and (e) Enthalpy in phase 5.

The data obtained in the commercial aviaries were used for validating the developed fuzzy model. Both the development and the simulations utilized the MATLAB's Fuzzy Toolbox ${ }^{\circledR}$ software, 7.13.0.564 (R2011b) version, in which the entire modeling was designed. The evaluation of the proposed models included a comparison of simulated and observed productive responses by means of standard deviation and percentage error.
The developed fuzzy model was the basis for simulations that were performed by considering enthalpy values for each breeding stage that characterized stress conditions due to cold, comfort, and heat stress.

The enthalpy comfort/discomfort limits (Table 2) for each phase of the broilers' lives were calculated through $t_{d b}$ and RH limits obtained by several authors (Medeiros et al., 2005; Cassuce et al., 2013; Cândido et al., 2016).

TABLE 2. Lower and upper limits of the optimal temperatures and enthalpies for the broilers at each stage of life.

\begin{tabular}{cccc}
\hline Stage of life & $\begin{array}{c}\text { Air temperature limits } \\
\left(\mathrm{t}_{\mathrm{db}},{ }^{\circ} \mathrm{C}\right)\end{array}$ & $\begin{array}{c}\text { Relative humidity } \\
(\mathrm{RH}, \%)\end{array}$ & $\begin{array}{c}\text { Enthalpy limits } \\
\left(\mathrm{H}, \mathrm{kJ} \mathrm{kg} \mathrm{dry} \mathrm{air}^{-1}\right)\end{array}$ \\
\hline 1 & $32-34$ & $60-80$ & $80-84.4$ \\
2 & $28-32$ & $60-80$ & $72-80$ \\
3 & $26-28$ & $60-80$ & $68.2-72$ \\
4 & $18-26$ & $60-80$ & $54.8-68.2$ \\
5 & $18-24$ & $60-80$ & $54.8-64.6$ \\
\hline
\end{tabular}


According to the combinations of birds' life stages and enthalpy (H) (Figure 5), 243 rules were defined, and for each rule, a weighting factor of 1 was assigned, as all rules have the same importance in determining the model responses, as adopted by several authors (Yanagi Junior et al., 2012; Ponciano et al., 2012; Schiassi et al., 2013; Schiassi et al., 2014).

The rules were defined in the form of linguistic sentences based on the data collected in the first phase of this experiment and with the support of specialists. We used the methodology proposed by Cornelissen et al. (2002) as employed by Yanagi Junior et al. (2012) and Schiassi et al. (2015) to choose the specialists. In this way, four experts, with over ten years of experience in animal ambience and fuzzy modeling, helped to set up the rules.

Based on the input variables and using the experimental data as a reference, the fuzzy models predicted the output variables FI, WG, FC and PEI, which were also characterized by trapezoidal pertinence curves (Figure 6). The defuzzification was carried out using the gravity center method (centroid or area center), which considers all output alternatives, converting the fuzzy set originated by the inference into numerical values (Leite et al., 2010).

The developed fuzzy model was the basis for simulations that were performed by considering enthalpy values for each breeding stage that characterized stress conditions due to cold, comfort, and heat stress.

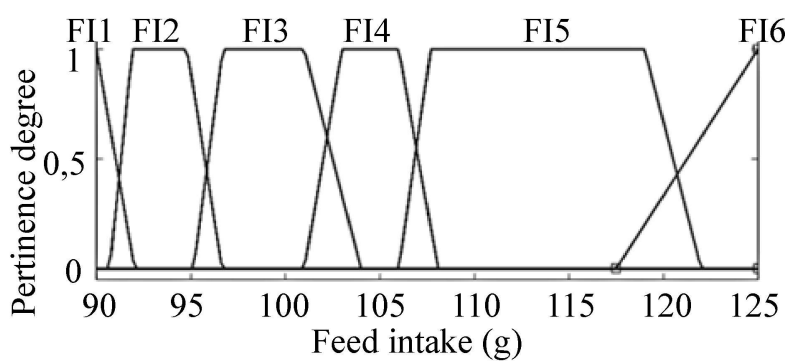

(a)

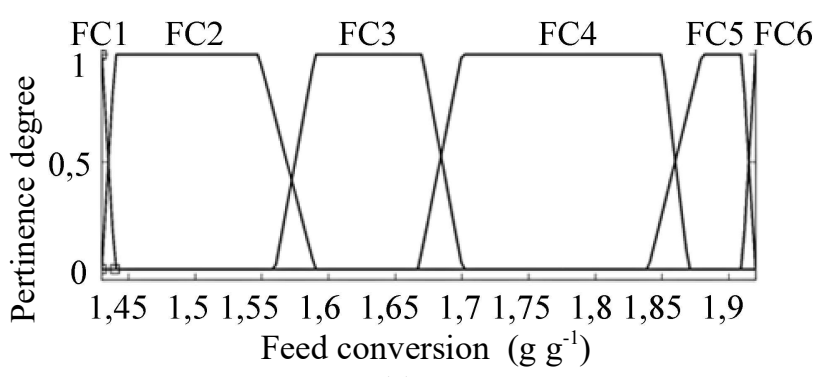

(c)

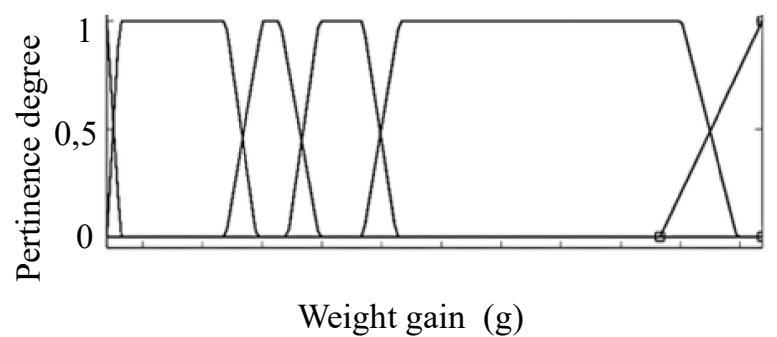

(b)

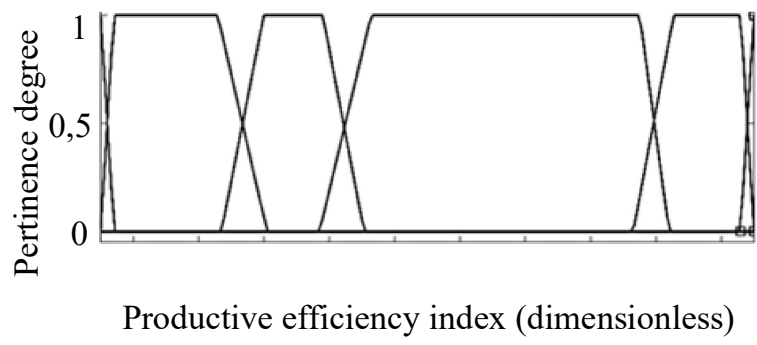

(d)

FIGURE 6. Pertinence functions for the output variables: (a) food intake (FI), (b) weight gain (WG), (c) feed conversion (FC), and (d) productive efficiency index (PEI).

\section{RESULTS AND DISCUSSION}

The fuzzy model adjustment was performed based on the data collected in the experiment (Table 3), and the interval for each pertinence function of each output variable was adopted to obtain the smallest possible error when the values were compared to the experimentally determined data. 
TABLE 3. Experimentally observed input and output mean values.

\begin{tabular}{|c|c|c|c|c|c|c|c|c|c|c|}
\hline \multirow{3}{*}{$\begin{array}{c}\text { Systems of commercial } \\
\text { production }\end{array}$} & \multirow{3}{*}{ Batches } & \multirow{2}{*}{\multicolumn{5}{|c|}{$\begin{array}{c}\text { Input Variables } \\
\text { Enthalpy in life stages } \\
\left(\mathrm{kJ} \mathrm{kg} \mathrm{dry} \mathrm{air}{ }^{-1}\right)\end{array}$}} & \multicolumn{4}{|c|}{ Output Variables } \\
\hline & & & & & & & \multirow{2}{*}{$\begin{array}{l}\text { FI } \\
\text { (g) }\end{array}$} & \multirow{2}{*}{ WG (g) } & \multirow{2}{*}{$\begin{array}{l}\mathrm{FC} \\
\left(\mathrm{g} \mathrm{g}^{-1}\right) \\
\end{array}$} & \multirow[t]{2}{*}{ PEI } \\
\hline & & 1 & 2 & 3 & 4 & 5 & & & & \\
\hline \multirow{6}{*}{ Dark house } & 1 & 74.98 & 66.52 & 67.91 & 66.79 & 65.18 & 132.01 & 3137 & 1.61 & 333 \\
\hline & 2 & 73.09 & 70.60 & 69.40 & 70.66 & 70.25 & 116.92 & 2807 & 1.47 & 387 \\
\hline & 3 & 74.85 & 72.57 & 70.36 & 68.98 & 65.08 & 108.72 & 2528 & 1.51 & 383 \\
\hline & 4 & 73.50 & 73.62 & 70.79 & 68.96 & 68.16 & 111.54 & 2546 & 1.49 & 392 \\
\hline & 5 & 73.21 & 73.68 & 70.85 & 68.98 & 67.02 & 124.54 & 3018 & 1.44 & 400 \\
\hline & 6 & 70.58 & 67.95 & 67.73 & 65.25 & 60.66 & 116.11 & 2820 & 1.45 & 406 \\
\hline \multirow{6}{*}{ Conventional } & 1 & 72.74 & 64.24 & 72.61 & 66.72 & 67.18 & 112.98 & 2422 & 1.90 & 268 \\
\hline & 2 & 74.27 & 70.67 & 70.29 & 72.24 & 72.59 & 109.14 & 2417 & 1.75 & 300 \\
\hline & 3 & 80.45 & 70.70 & 71.94 & 70.04 & 69.30 & 109.42 & 2469 & 1.70 & 214 \\
\hline & 4 & 69.64 & 73.51 & 71.24 & 70.90 & 68.98 & 119.21 & 2985 & 1.55 & 347 \\
\hline & 5 & 73.87 & 70.46 & 68.05 & 69.31 & 65.06 & 118.87 & 2818 & 1.70 & 314 \\
\hline & 6 & 77.97 & 73.26 & 74.67 & 70.30 & 63.89 & 116.45 & 2815 & 1.58 & 352 \\
\hline \multirow{6}{*}{ Negative Pressure } & 1 & 73.15 & 66.46 & 73.95 & 68.24 & 67.70 & 119.32 & 2730 & 1.65 & 328 \\
\hline & 2 & 73.24 & 74.02 & 72.13 & 73.30 & 71.85 & 100.59 & 2113 & 1.68 & 325 \\
\hline & 3 & 77.84 & 75.79 & 71.24 & 70.04 & 68.84 & 121.40 & 3081 & 1.46 & 370 \\
\hline & 4 & 78.03 & 75.88 & 71.73 & 70.20 & 69.10 & 114.72 & 2829 & 1.46 & 393 \\
\hline & 5 & 77.11 & 73.27 & 70.75 & 69.39 & 67.48 & 114.28 & 2888 & 1.45 & 383 \\
\hline & 6 & 73.20 & 71.82 & 73.07 & 68.46 & 65.32 & 112.89 & 2827 & 1.44 & 404 \\
\hline
\end{tabular}

Legend: FI - food intake, WG - weight gain, FC - feed conversion, and PEI - productive efficiency index.

Thus, the FI, WG, FC and PEI values simulated by the fuzzy model as a function of enthalpy in broilers' life stages were compared to the experimentally obtained data (Table 4). It can be observed that the fuzzy model was able to predict FI, WG, and FC in different commercial broiler production systems. The mean standard deviations of 4.16 $\mathrm{g}, 146.53 \mathrm{~g}$, and $0.06 \mathrm{~g} \mathrm{~g}^{-1}$, respectively, and mean percent errors of $5.05,8.04$, and $4.96 \%$, respectively, were obtained for FI, WG, and FC.

Some authors using fuzzy modeling to predict the productive performance of broilers from 1 to 21 days of age obtained mean standard deviations and percentage errors for FI, WG and FC as $4.31 \mathrm{~g}$ and $2.38 \%, 4.76 \mathrm{~g}$ and $2.94 \%$, and $0.02 \mathrm{~g} \mathrm{~g}^{-1}$ and $2.16 \%$, respectively (Ponciano et al., 2012) and $4.15 \mathrm{~g}$ and $2.12 \%, 3.10 \mathrm{~g}$ and $2.74 \%$, and $0.03 \mathrm{~g} \mathrm{~g}^{-1}$ and $1.94 \%$, respectively (Schiassi et al., 2015).

The standard and percentage errors obtained in this study were higher than those observed by Ponciano et al.
(2012) and Schiassi et al. (2015) because the studies were carried out in acclimatized wind tunnels with control of thermal conditions and management. Furthermore, the experiment time was limited to the first three weeks of the chickens' lives. As the model in this study was developed and validated with data from commercial production systems with different technological levels, different batches of animals, and covering the entire production cycle of the chickens, the observed increase in the standard deviations and percentage errors can be considered as acceptable (Tavares \& Schiassi, 2016).

Response surfaces adjusted by Medeiros (2001) from laboratory experiments determining the FI, WG, and $\mathrm{FC}$ of adult chickens as functions of $\mathrm{t}_{\mathrm{db}}, \mathrm{RH}$, and air speed had standard deviations and percentage error values of 2.36 $\mathrm{g}$ and $2.79 \%$ for FI, $2.02 \mathrm{~g}$ and $4.97 \%$ for $\mathrm{WG}$, and $0.08 \mathrm{~g}$ $\mathrm{g}^{-1}$ and $5.67 \%$ for $\mathrm{FC}$, respectively. 
TABLE 4. Comparison of experimentally obtained and predicted feed conversion ( $\left.\mathrm{FC}, \mathrm{g} \mathrm{g}^{-1}\right)$, mean weight gain (WG, $\mathrm{g}$ ), food intake (FI, g) and productive efficiency index (PEI) values as functions of enthalpy and broilers' life stage.

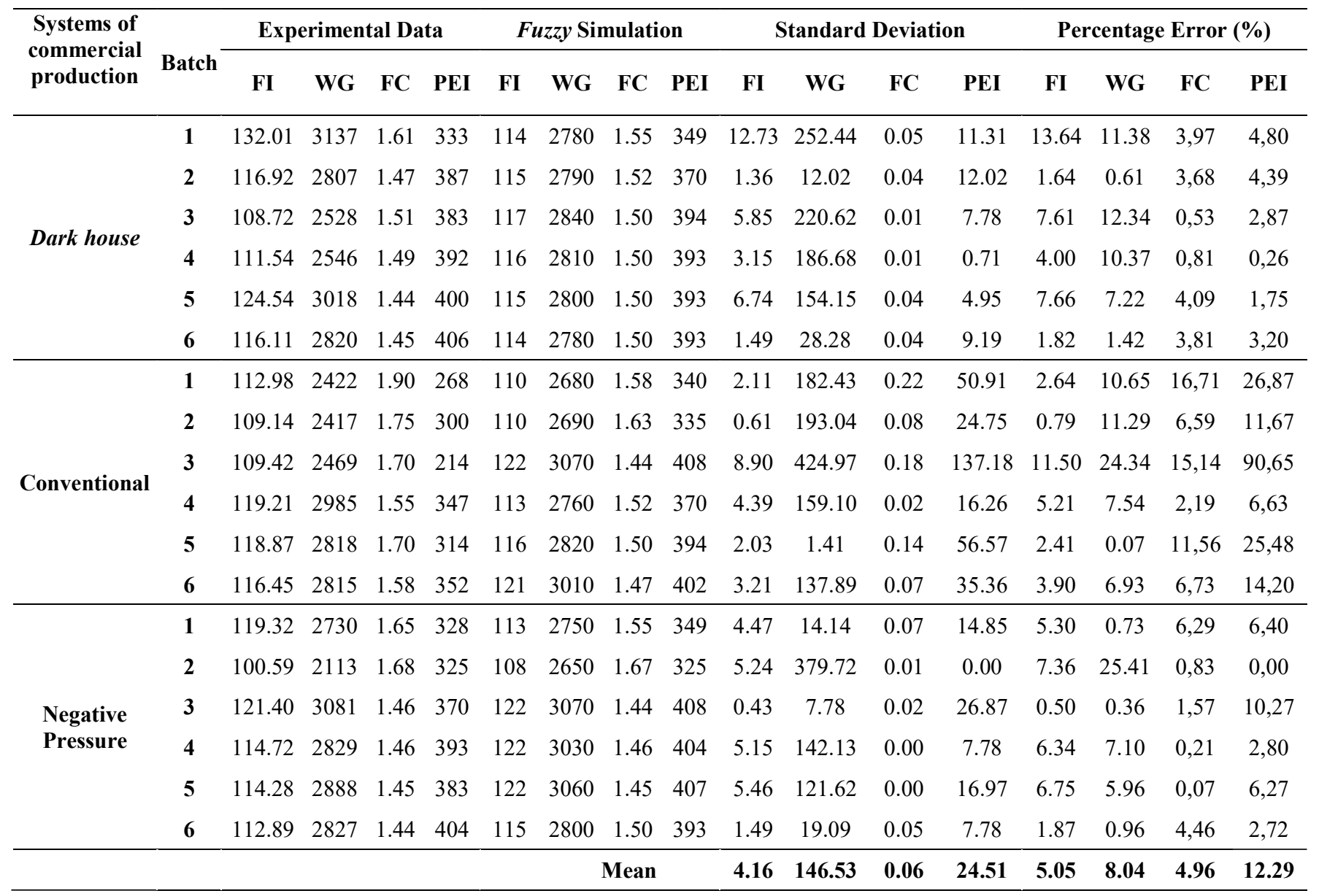

By analyzing the FC and PEI values of the broilers as a function of the batches and the different evaluated commercial production systems, a large variation in the experimentally measured data was observed (Table 4). The results of the developed fuzzy model were adapted to these variations, with the exception of batches 1,3 , and 5 of the conventional commercial production system, which obtained percentage errors above $10 \%$, as the conventional production system has a low control of the internal environment and all handling operations are carried out manually, thus enabling a high variation in animals' productive responses.

According to the Broiler Performance and Nutrition Supplement (Cobb-Vantress, 2015), the cumulative feed conversion for male broilers at 42 days of life is around $1.667 \mathrm{~g} \mathrm{~g}^{-1}$. In this study, the mean feed conversion value found for each evaluated system was $1.49 \mathrm{~g} \mathrm{~g}^{-1}$ for the dark house system, $1.68 \mathrm{~g} \mathrm{~g}^{-1}$ for the conventional system, and $1.52 \mathrm{~g} \mathrm{~g}^{-1}$ for the negative pressure system.
The productive performance of broilers raised in the dark house and negative pressure systems are close to the values expected for the lineage (Cobb-Vantress, 2015), and for the conventional system, they are slightly higher (1.68). Among the systems, the most efficient system, regarding feed conversion, was the dark house, followed by the negative pressure system, and finally, the conventional system, a result that reflects the different system control levels.

Simulations with the fuzzy system (Table 5) indicate that, independently of the breeding stage, the thermal stress conditions cause a reduction in broilers productive performance. In the initial breeding phase, it is observed that chickens are more sensitive to cold stress than to heat, results that corroborate the work done by Abreu et al. (2015). In turn, in the termination phase, the converse is observed. 
TABLE 5. Evaluating the different enthalpy levels in different stages of animals' life predicted with the fuzzy model.

\begin{tabular}{|c|c|c|c|c|c|c|c|c|c|}
\hline & \multicolumn{5}{|c|}{ Input variables } & \multicolumn{4}{|c|}{ Output variables } \\
\hline & \multicolumn{5}{|c|}{ Enthalpy (kJ kg dry air $\left.{ }^{-1}\right)$ in breeding stages } & \multicolumn{4}{|c|}{ Productive performance } \\
\hline & 1 & 2 & 3 & 4 & 5 & FI $\left(\mathrm{g} \mathrm{g}^{-1}\right)$ & WG (g) & $\mathrm{FC}(\mathrm{g})$ & PEI \\
\hline 1 & 82.2 & 76 & 70.1 & 61.5 & 59.7 & 123 & 3080 & 1.43 & 409 \\
\hline 2 & 92.2 & 76 & 70.1 & 61.5 & 59.7 & 121 & 2970 & 1.48 & 400 \\
\hline 3 & 82.2 & 90 & 70.1 & 61.5 & 59.7 & 117 & 2850 & 1.50 & 395 \\
\hline 4 & 82.2 & 76 & 86 & 61.5 & 59.7 & 114 & 2770 & 1.50 & 393 \\
\hline 5 & 82.2 & 76 & 70.1 & 84.1 & 59.7 & 114 & 2770 & 1.50 & 393 \\
\hline 6 & 82.2 & 76 & 70.1 & 61.5 & 82.3 & 114 & 2770 & 1.50 & 393 \\
\hline 7 & 60 & 76 & 70.1 & 61.5 & 59.7 & 114 & 2770 & 1.50 & 393 \\
\hline 8 & 82.2 & 56 & 70.1 & 61.5 & 59.7 & 114 & 2770 & 1.50 & 393 \\
\hline 9 & 82.2 & 76 & 54.1 & 61.5 & 59.7 & 114 & 2770 & 1.50 & 393 \\
\hline 10 & 82.2 & 76 & 70.1 & 47.4 & 59.7 & 114 & 2790 & 1.50 & 393 \\
\hline 11 & 82.2 & 76 & 70.1 & 61.5 & 47.4 & 114 & 2790 & 1.50 & 393 \\
\hline 12 & 60 & 56 & 70.1 & 61.5 & 59.7 & 105 & 2430 & 1.63 & 332 \\
\hline 13 & 92.2 & 90 & 70.1 & 61.5 & 59.7 & 117 & 2830 & 1.52 & 368 \\
\hline 14 & 82.2 & 76 & 54.1 & 47.4 & 47.4 & 105 & 2600 & 1.71 & 311 \\
\hline 15 & 82.2 & 76 & 86 & 84.1 & 82.3 & 99.2 & 2320 & 1.77 & 269 \\
\hline 16 & 82.2 & 76 & 70.1 & 47.4 & 47.4 & 105 & 2670 & 1.59 & 337 \\
\hline 17 & 82.2 & 76 & 70.1 & 84.1 & 82.3 & 105 & 2430 & 1.63 & 332 \\
\hline
\end{tabular}

Key: Green background: mean thermal comfort value; red background: mean heat stress value; and blue background: mean cold stress value.

\section{CONCLUSIONS}

The proposed fuzzy model allows for the efficient estimation of the average daily food intake, weight gain, feed conversion, and productive efficiency index of broilers raised in different commercial production systems existing in the sector.

\section{ACKNOWLEDGEMENTS}

The authors thank FAPEMIG, CAPES, CNPq, and EMBRAPA Swine and Poultry for their support to this research.

\section{REFERENCES}

Aborisade DO, Stephen O (2014) Poultry house temperature control using Fuzzy-PID controller. 11(6):310-314.

Abreu LH, Yanagi Junior T, Fassani ÉJ, Campos AT, Lourençoni D (2015) Fuzzy modeling of broiler performance, raised from 1 to 21 days, subject to heat stress. Engenharia Agrícola 35(6):967-978.

Abreu PG de, Abreu VMN, Coldebella A, Hassemer MJ, Tomazelli IL (2012) Medidas morfológicas em função do peso e da idade da ave, por meio de imagens. Revista Brasileira de Engenharia Agrícola e Ambiental 16(7):795801.

Albright LD (1990) Environment control for animals and plants. St. Joseph, American Society of Agricultural Engineers Michigan, 453p.

Almeida EA, Passini R (2013) Conforto térmico em modelos reduzidos de casas de frangos de corte, sob diferentes tipos de materiais de cobertura. Engenharia Agrícola 33(1):19-27.
Baracho MS, Cassiano JA, Nääs IA, Tonon GS, Garcia RG, Royer AFB, Santana MR (2013) Ambiente interno em galpões de frango de corte com cama nova e reutilizada. Agrarian 6(22):473-478.

Boiago MM, Barba H, Souza PA, Scatolini AM, Ferrari FB, Giampietro-Ganeco A (2013) Desempenho de frangos de corte, alimentados com dietas contendo diferentes fontes de selênio, zinco e manganês, criados sob condições de estresse térmico. Arquivo Brasileiro de Medicina Veterinária e Zootecnia 65(1):241-247.

Campos AT, Castro JO, Schiassi L, Yanagi Junior T, Pires MFÁ, Mattioli CC (2013a) Prediction of free-stall occupancy rate in dairy cattle barns through fuzzy sets. Engenharia Agrícola 33(6):1079-1089.

Campos AT, Klosowski ES, Sousa FA, Ponciano PF, Navarini FC, Yanagi Junior T (2013b) Eficiência de sistema de aquecimento auxiliar para aviários, com base nos índices de conforto térmico. Bioscience Journal 29(3):703-711.

Cândido MG, Tinôco IDF, Pinto FDADC, Santos NT, Roberti RP (2016) Determination of thermal comfort zone for early-stage broilers. Engenharia Agrícola 36(5):760-767.

Cassuce DC, Tinoco IDF, Baeta FC, Zolnier S, Cecon PR, Vieira MDA (2013) Atualização da temperatura de conforto térmico para frangos de corte de até 21 dias de idade. Engenharia Agrícola 33(1):28-36.

Castro JO (2014) Avaliação e modelagem do desempenho de codornas japonesas em postura submetidas a diferentes ambientes térmicos. Tese Doutorado, Universidade Federal de Lavras. 
Castro JO, Veloso AV, Yanagi Junior T, Fassani EJ, Schiassi L, Campos AT (2012) Estimate of the weight of Japanese quail eggs through fuzzy sets theory. Ciência e Agrotecnologia 36(1):108-116.

COBB (2015) Suplemento de nutrição e desempenho do frango de corte. Cobb-Vantress, 14 p. Available in: http://www.cobb-vantress.com/ languages/guidefiles/fa217990-20c9-4ab1-a54e3bd02d974594_pt.pdf. Accessed: Jan 20, 2016.

Cornelissen AMG, Van Den Berg J, Koops WJ, Kaymak U (2002) Elicitation of expert knowledge for fuzzy evaluation of agricultural production systems. Agriculture, Ecosystems \& Environment 95(1):1-18.

Ferraz PFP, Yanagi Junior T, Julio YFH, Castro JO, Gates RS, Reis GM, Campos AT (2014) Predicting chick body mass with artificial intelligence-based models. Pesquisa Agropecuária Brasileira 49(7):559-568.

Gates RS, Chao K, Sigrimis N (2001) Identifying design parameters for fuzzy control of staged ventilation control systems. Computers and Electronics in Agriculture 31(1):61-74.

Julio YFH, Yanagi Junior T, Pires MFA, Lopes MA, Lima RR (2015) Fuzzy system to predict physiological responses of Holstein cows in southeastern Brazil. Revista Colombiana de Ciências Pecuárias 28(1):42-53.

Lara LJ, Rostagno MH (2013) Impacto do estresse térmico sobre a produção de aves. Animals 3(2):356-369.

Leite MS, Fileti AMF, Silva FV (2010) Desenvolvimento e aplicação experimental de controladores fuzzy e convencional em um bioprocesso. Revista Controle e Automação 21(2):147-158.

Lin CS, Yeh PT, Chen DC, Chiou YC, Lee CH (2013) The identification and filtering of fertilized eggs with a thermal imaging system. Computers and Electronics in Agriculture 91:94-105.

Mandani EH (1976) Advances in the linguistic syntesis of fuzzy controllers. International Journal of Man-Machine Studies 8(6):669-678.

Medeiros CM (2001) Ajuste de modelos e determinação de índice térmico ambiental de produtividade para frangos de corte. Tese Doutorado, Universidade Federal de Viçosa.

Medeiros CM, Baêta FC, Oliveira RFM (2005) Efeitos da temperatura, umidade relativa e velocidade do ar em frangos de corte. Engenharia na Agricultura 13(4):277-286.

Mirzaee-Ghalehv E, Omid M, Keyhani A, Dalvand MJ (2015) Comparison of fuzzy and on/off controllers for winter season indoor climate management in a model poultry house. Computers and Electronics in Agriculture 110:187-195.

Múnera Bedoya OD, Yanagi Junior T, Ávila Pires MF, Aurélio Lopes M, Ribeiro de Lima R (2015) Fuzzy system to predict physiological responses of Holstein cows in southeastern Brazil. Revista Colombiana de Ciências Pecuárias 28(1):42-53.
Nascimento GR, Nääs IA, Baracho MS, Pereira DF, Neves DP (2014) Termografia infravermelho na estimativa de conforto térmico de frangos de corte. Revista Brasileira de Engenharia Agrícola e Ambiental 18(6):658-663.

Peel MC, Finlayson BL, Mcmahon TA (2007) Updated world map of the Köppen-Geiger climate classification. Hydrology Earth System Sciences 11:1633-1644.

Ponciano PF, Yanagi Junior T, Schiassi L, Campos AT, Nascimento JWB (2012) Sistema fuzzy para predição do desempenho produtivo de frangos de corte de 1 a 21 dias de idade. Engenharia Agrícola 32(3):446-458.

Santos GB, Sousa IF, Brito CO, Santos VS, Barbosa RJ, Soares C (2014) Estudo biológico das regiões litorâneas, agreste e semiárida do estado de Sergipe para a avicultura de corte e postura. Ciência Rural 44(1):123-128.

Schiassi L, Melo NSM, Tavares GF, Souza ÍP, Araújo HB, Della Giustina C (2013) Modelagem fuzzy em parâmetros de bem-estar humano. Nativa 1(1):8-12.

Schiassi L, Yanagi Junior T, Damasceno FA, Saraz JAO, Amaral AG (2014) Thermal-Acoustic Comfort Index for Workers of Poultry Houses Using Fuzzy Modeling. International Journal of Engineering Research and Applications 4(9):60-64.

Schiassi L, Yanagi Junior T, Reis GM, Abreu LHP, Campos AT, Castro JO (2015) Modelagem fuzzy aplicada na avaliação do desempenho de frangos de corte. Revista Brasileira de Engenharia Agrícola e Ambiental 19(2):140146.

Tavares GF, Schiassi L (2016) Modelagem fuzzy como ferramenta para predição do ganho de peso diário para frangos de corte. Journal of Animal Behaviour and Biometeorology 4(2):32-38.

Tinôco IFF, Souza CF, Baêta FC, Coelho DJR, Mendes MASA (2014) Ambiencia e instalações na avicultura de postura brasileira: avanços e perspectivas. Animal Busineess Brasil 4(14):6-9.

Xiang-Jie N (2014) Research on the temperature control algorithm of the poultry farm. Applied Mechanics and Materials 602:1206-1209.

Yanagi Junior T, Amaral AG, Teixeira VH, Lima RR (2011) Caracterização espacial do ambiente termoacústico e de iluminância em galpão comercial para criação de frangos de corte. Engenharia Agrícola31(1):1-12.

Yanagi Junior T, Schiassi L, Abreu LHP, Barbosa JA, Campos AT (2012) Procedimento fuzzy aplicado à avaliação da insalubridade em atividades agrícolas. Engenharia Agrícola 32(3):423-434.

Zare Mehrjerdi MR, Ziaabadi M, Ayatollahi Mehrgardi A, Dayani O (2015) Comparison of fuzzy and on/off controllers for winter season indoor climate management in a model poultry house. Journal of Livestock Science and Technologies 3(1):34-40. 